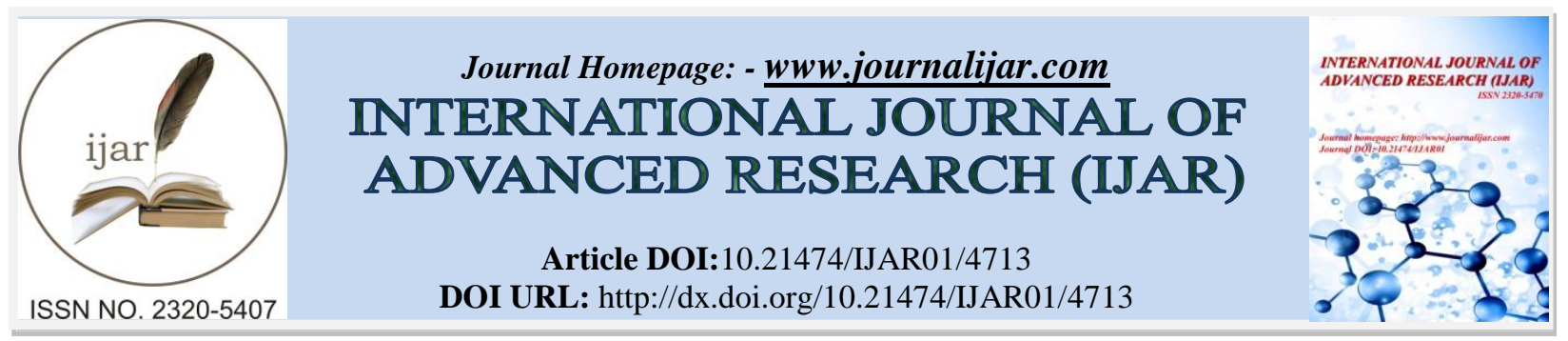

RESEARCH ARTICLE

\title{
IMPLEMENTATION OF MGNREGA IN J\&K: PERFORMANCE AND CREATION OF ASSETS IN KISHTWAR DISTRICT.
}

Hakim Singh.

PHD Scholar, Department of Public Policy and Public Administration, Central University of Jammu, Jammu and Kashmir, India

\section{Manuscript Info}

Manuscript History

Received: 3 May 2017

Final Accepted: 5 June 2017

Published: July 2017

Key words:-

MGNREGA, Performance, Rural

Infrastructure, Kishtwar.

\begin{abstract}
Origin of MGNREGA Act, 2005 is a revolutionary step to the process of policy implementation in India. It has immensely affected the socio-economic security of rural citizens as it provides 100 days of guaranteed employment to every household whose adult members is willing to do unskilled manual work at fixed minimum wages. The scheme (MGNREGA) in Kishtwar region (then a tehsil of erstwhile Doda) was implemented in the first phase. For instance, the district at that time being a tehsil was covered under the scheme in the year 2006-07. So with this background the present study was an attempt to study the implementation of MGNREGA-performance and its role in developing the rural infrastructure (Assets) in district Kishtwar. It also explored the various trends in implementing the scheme in the District.
\end{abstract}

Copy Right, IJAR, 2017,. All rights reserved.

\section{Introduction:-}

India is divided into various categories and among which rural and urban divide is the most significant to cover the all others. Majority of the population lives in villages. After the political independence from British Empire, Government of India initiated various programmes/schemes to bridge the rural and urban gap. For instance, Development programmes were initiated from time to time so as to address the issue of poverty, unemployment and lack of rural infrastructure.

In third world countries Poverty alleviation programmes are seen as means of overcoming the drawbacks of markets. Accordingly, sophisticated programmes were often implemented without rural root. Therefore, MGNREGA as a programme was launched by the Government of India in the year 2005 with the main objective to ensure livelihood security of the rural poor. The programme provides hundred days of guaranteed employment to every household in every financial year whose adult members is willing to do unskilled labour work. The scheme was also initiated with the intensions of creating the rural infrastructure for betterment of villages.

The act covered 200 rural districts in first phase, implemented on February, 2, 2006 and was extended to an additional 130 districts in 2007-08. All the remaining rural areas have been notified with effect from April, 12008. Since 2008, this programme has covered the entire country with the exception of districts that have a 100 percent of urban population. The Government of India on $2^{\text {nd }}$ October 2009 renamed this programme NREGA as Mahatma Gandhi National Rural Employment Guarantee Act.

Corresponding Author:-Hakim Singh. Address:-PHD Scholar, Department of Public Policy and Public Administration, Central University of Jammu, Jammu and Kashmir, India. 
The evolution of MGNREG scheme can be traced from Employment Guarantee Scheme (EGS) that was first introduced in Maharashtra in 1973. Employment scheme under MGNREGA differs from previous employment programs as it is endorsed by a law enacted by the Indian Parliament in 2005. The work provided under the right to employment gives opportunity to earn wages and create durable productive assets (Mishra, 2011). The scheme has been introduced with the intensions of creating assets which would enhance productivity along with an increase in demand for labour in rural areas (Haque, 2011). Before introducing the MGNREGA scheme many programmes have been initiated to improve the employment generation which only provided a relief type employment chances rather than creating productive assets (Kantharaju, 2011).

\section{Objectives of the Study:-}

1. To study the implementation of the MGNREGA scheme in district Kishtwar.

2. To explore the performance of the scheme in the district.

3. To identify various assets developed under MGNREGA scheme in the district.

\section{Research Methodology:-}

Methodology plays an important role in the research work. It not only helps the researcher to formulate research questions but also assists in resolving various issues related to his research work systematically. Present study is an attempt to study the implementation of MGNREGA, performance and its role in creating assets in district Kishtwar of J\&K state. The study was based on both primary as well as secondary data. Primary data had been collected through various group discussions, personal interviews, worksite visits etc. while as secondary data has been collected from various reports, journals, books and also from MGNREGA website. For the collection of primary data a total sample of 200 MGNREGA workers (100 beneficiaries from block Kishtwar\& 100 workers from block Drabshalla) were selected for the study.

\section{Implementation of MGNREGA:-}

Poverty and rural unemployment are the two acute problems facing India and act as a drag on economic and social development. After years of planning the Mahatma Gandhi Rural Employment Guarantee Act (MGNREGA) was a well thought of measure to make a dent in poverty on our villages by delivering cash in hands of workers for work done under various heads to improve rural infrastructure. MGNREGA, the largest poverty alleviation programme initiated by the Government of India in the year 2005 has a significant objective to provide a legal guarantee of 100 days of employment to every rural household, whose adult members are willing to do unskilled labour at minimum wage rate. Programme also envisages the creation of sustainable community assets besides protecting environment, reducing migration \& empowering rural women. The programme initially covered 200 districts. In J\&K the Act was extended partially in May 2007 \& to the whole of the state since April 2008.

\section{Guidelines of the MGNREGA Act, 2005:-}

The main characteristics of the scheme are as under:

1. To ensure livelihood security for the poor through creation of durable assets, improved water security, soil conservation and higher land productivity.

2. Strengthening drought-proofing and flood management in rural India.

3. Deepening democracy at the grass-roots by strengthening Panchayati Raj Institutions.

4. Effecting greater transparency and accountability in governance. Thus, MGNREGA has become a powerful instrument for inclusive growth in rural India through its impact on social protection, livelihood security and democratic governance.

5. Strengthening decentralized and participatory planning through convergence of various anti-poverty and livelihoods initiatives.

6. Empowerment of the socially disadvantaged, especially women, scheduled castes and schedule tribes through the process of a rights-based legislation.

7. To provide social protection for the most vulnerable people living in rural India by providing employment opportunities. At least 100 days of guaranteed wage employment in a financial year.

8. An annual shelf of works to be prepared in advance for each year.

9. A ratio of 60:40 for wage and material costs should be maintained at Gram Panchayat level.

10. No contractors/and no labour-displacing machinery shall be used in execution of works.

11. Panchayati Raj Institutions will have a principal role in planning, monitoring and implementation

12. At least one-third of the workers should be women. 


\section{Permissible works under the MGNREGA:-}

Various types of works permissible under the scheme are:

1. Water conservation and water harvesting including contour trenches, contour bunds, boulder checks, gabion structures, underground dykes, earthen dams, stop dams and spring shed development;

2. Drought proofing including afforestation and tree plantation;

3. Irrigation canals including micro and minor irrigation works;

4. Provision of irrigation facility, dug out farm pond, horticulture, plantation, farm bonding and land development;

5. Renovation of traditional water bodies including desalting of tanks;

6. Land development;

7. Flood control and protection works including drainage in water logged areas including deepening and repairing of flood channels, chaur renovation, construction of storm water drains for coastal protection;

8. Rural connectivity to provide all weather access, including culverts and roads within a village, wherever necessary;

9. Construction of Bharat Nirman Rajiv Gandhi Sewa Kendra as Knowledge Resource Centre at the Block level and as Gram Panchayat Bhawan at the Gram Panchayat level;

10. Agriculture related works, such as, NADEP composting, vermi-composting, liquid bio-manures;

11. Livestock related works, such as, poultry shelter, goat shelter, construction of pucca floor, urine tank and fodder trough for cattle, azolla as cattle-feed supplement;

12. Fisheries related works, such as, fisheries in seasonal water bodies on public land;

13. Works in coastal areas, such as, fish drying yards, belt vegetation;

14. Rural drinking water related works, such as, soak pits, recharge pits;

15. Rural sanitation related works, such as, individual household latrines, school toilet units, Anganwadi toilets, solid and liquid waste management;

16. Construction of Anganwadi centers

17. Construction of play fields.

18. Any other work which may be notified by the Central Government in consultation with the State Government.

\section{Implementation of MGNREGA in Kishtwar district of Jammu and Kashmir:-}

MGNREGA came into existence in 2005 but was extended to Jammu and Kashmir in fifteenth of May 2007. The districts namely erstwhile Doda, Kupwara, Poonch, Anantnag and Jammu were notified for coverage under the scheme with effect from sixth of June 2007 vide notification no 28012/10/2005-NREGA dated fourteenth of June 2007. All the rest of districts in the state were covered consequently under the scheme in 2008 . The scheme is under implementation in all the newly created districts with effect from the date from which the original districts had been notified for coverage under the act. However, for the purpose of release of funds to these newly created districts for implementation of NREGA the central government identifies the districts as independent NREGA districts. At present, this scheme is under implementation in all the districts of the State w. e. f 01.04.2008. The main objective of this scheme is to provide 100 days of guaranteed unskilled wage employment to each rural household opting for it. During the year 2013-14 an amount of Rs. 709.01 crores was available under MGNREGS, out of which Rs. 766.54 crores (96\%) was utilized/spent. 1139252 numbers of households were issued job cards and 328.73 lakh person/days employment was generated. During the year 2014-15 (ending November, 2014), against an available funds of Rs.311.77crores, an amount of Rs. 260.59 crores (83\%) was utilized/spent. 18099 number of households were issued job cards and 71.90 lakh person/days employment was generated. Theoretically, scheme is demand driven and envisages coverage of not only below poverty level (BPL) families but also the families from above poverty line (APL) willing to do manual work on minimum wages notified by the state under Minimum Wages Act. The scheme is aimed at to create visible impact, which must result in the transformation of rural economy of the state. More sensitization among stakeholders is should be created to ensure more effective implementation of the scheme. The scheme to the state of Jammu and Kashmir was formulated by the state government with confirmation to section 4 and the legally non-negotiable parameters laid down in the schedules I and II of the Act. Implementation of the scheme in the state has to be made consistent with the operational parameters determined in the guidelines under the Act.

\section{Results and Discussions:-}

There are many factors that highlight the implementation of MGNREGA in any part of rural India. Following tables are significant in exploring, identifying and studying the implementation of the scheme with special reference to its performance and creation of Assets in the study area. 
Table No. 1:- Awareness level of MGNREGA Workers about daily wage rate

\begin{tabular}{ccccc}
\hline Blocks & Panchayats & Yes (In \%) & No (In \%) & Do not Know (In \%) \\
\hline Kishtwar & Pochhal A 1 & 30.12 & 0 & 69.88 \\
& Pochhal A 2 & 30 & 0 & 70 \\
Drabshalla & Ghan & 15.25 & 0 & 84.75 \\
& Pora Chandalli & 10 & 0 & 90 \\
\hline
\end{tabular}

Source: Field Survey, 2016

Table No. 2:-Awareness about Extra Compensation, Unemployment Allowance and Radius of Work Site

\begin{tabular}{ccccc}
\hline Block & Villages & Yes (In \%) & No (In \%) & Do not Know (In \%) \\
\hline Kishtwar & Pochhal A 1 & 0 & 0 & 100 \\
Drabshalla & Pochhal A 2 & 0 & 0 & 100 \\
& Ghan & 0 & 0 & 100 \\
& Pora Chandalli & 0 & 0 & 100 \\
\hline
\end{tabular}

Source: Field Survey, 2016

NREGA is a unique scheme to redefine avenues of providing employment opportunities to the masses in rural India. But the possibility and efficient opportunity of employment largely depends upon the better level of awareness as it marks the level of accessibility. This issue of awareness has been emerged as one of the hindrances to the workers. Implementing the scheme also needs such a perspective as low awareness level is commonly prevalent in most of the study areas. The table No. 1 has been discussed in this regard. For instance, the general awareness of the respondents, 30.12 per cent in Pochhal A 1, 30 percent in Pochhal A 2, only 15.25 percent in Ghan and 10 per cent in Pora-Chandalli said that they knew about stipulated minimum wages in the state. This again confirms to the fact that majority of the respondents did not know about minimum wages which largely influenced the possibility on the part of workers to assert for their entitled rights.

In the case of workers awareness about extra compensation, unemployment allowance and radius of working, none of the workers in all four panchayats were aware about these provisions. Hence, there is a great deal of work that needs to be carried out as far as awareness, fair implementation and assurance of accessibility was concerned (see Table No 2).

Table No. 3:- Job Card Holder's Profile in District Kishtwar

\begin{tabular}{|c|c|c|c|c|c|c|c|}
\hline Block & Panchayat (P) & \multicolumn{6}{|c|}{ Profile of MGNREGA Workers } \\
\hline \multirow{4}{*}{$\begin{array}{c}\text { Kishtwa } \\
\text { r }\end{array}$} & & \multicolumn{2}{|c|}{ Muslim/Tribe } & \multicolumn{4}{|c|}{ Hindu } \\
\hline & & Male & Female & Total of Ps & Male & Female & Total of Ps \\
\hline & Pochhal A 1 & 86 & 41 & 127 & 97 & 86 & 183 \\
\hline & Pochhal A 2 & 159 & 130 & 289 & 172 & 128 & 300 \\
\hline & Total & 245 & 171 & & 269 & 214 & \\
\hline \multicolumn{2}{|c|}{ Total of both M \& F } & \multicolumn{2}{|c|}{416} & & \multicolumn{2}{|c|}{483} & \\
\hline \multirow{2}{*}{$\begin{array}{c}\text { Drabsha } \\
\text { lla }\end{array}$} & Pora Chandalli & 238 & 3 & 241 & 68 & 22 & 90 \\
\hline & Ghan & 70 & 64 & 134 & 109 & 9 & 118 \\
\hline \multicolumn{2}{|c|}{ Total } & 308 & 67 & & 177 & 31 & \\
\hline \multicolumn{2}{|c|}{ Total of Both M \& F } & \multicolumn{2}{|c|}{375} & & \multicolumn{2}{|c|}{208} & \\
\hline
\end{tabular}

Source: mgnrega.nic.in

Table 3 highlighted the socio-cultural status of MGNREGA workers in the study area. So far as religious status of MGNREGA workers is concerned, it is evident from the table that majority of the beneficiaries are Hindus in three study panchayats i.e. (183) respondents in case of panchayat Pochhal A 1 while as 300 respondents in case of Panchayat Pochhal A 2 and 118 in Ghan. On the other hand panchayat Pora-Chandalli has Muslim majority workers. As far respondents having gender differentiation is concerned, there were 171+214=385 female respondents in block Kishtwar and 67+31+ 98 female respondents in block Drabshalla as compared to $245+269=514$ and $308+117=485$ of male respondents in the both respective blocks of Kishtwar district. Further it was inferred from the field that there was also good participation from the respondents having family size of more than 10 members as observed 
during the field survey. Now so far as social class of the respondents is concerned, majority of the beneficiaries in Pora-Chandalli panchayat of Drabshalla block were scheduled tribes.

This was followed by the respondents having general category. This thus means that MGNREGA provided employment to all categories of people. Further it was noticed that all of the respondents in Kishtwar block were having occupation other than agriculture as compared to Block Drabshalla in which Majority of respondents were having occupation as agriculture.

Table No. 4:- No of Households completed 100 days of Wage Employment

\begin{tabular}{|c|c|c|c|c|c|c|c|c|c|}
\hline \multirow[t]{3}{*}{ Block } & \multirow{3}{*}{$\begin{array}{l}\text { Villages } \\
\text { Total HHs \& Total No of HHs } \\
\text { Completed } 100 \text { days }\end{array}$} & \multicolumn{8}{|c|}{$\begin{array}{c}\text { Total No of HHs Completed } 100 \text { Days of Wage } \\
\text { Employment }\end{array}$} \\
\hline & & \multicolumn{2}{|c|}{ 2013-14 } & \multicolumn{2}{|c|}{ 2014-15 } & \multicolumn{2}{|c|}{ 2015-16 } & \multicolumn{2}{|c|}{ 2016-17 } \\
\hline & & $\mathrm{T}$ & 100 & $\mathrm{~T}$ & 100 & $\mathrm{~T}$ & 100 & $\mathrm{~T}$ & 100 \\
\hline \multirow{2}{*}{ Kishtwar } & Pochhal A 1 & 222 & 29 & 275 & 52 & 338 & 74 & 174 & 75 \\
\hline & Pochhal A 2 & 302 & 25 & 318 & 16 & 301 & 76 & 174 & 130 \\
\hline \multicolumn{2}{|r|}{ Total } & 524 & 54 & 593 & 68 & 639 & 150 & 348 & 205 \\
\hline \multirow{2}{*}{ Drabshalla } & Pora Chandalli & 294 & 228 & 304 & 6 & 310 & 1 & 321 & 178 \\
\hline & Ghan & 238 & 204 & 246 & 2 & 237 & 1 & 253 & 171 \\
\hline \multicolumn{2}{|r|}{ Total } & 532 & 432 & 550 & 8 & 547 & 2 & 574 & 349 \\
\hline
\end{tabular}

Source: mgnrega.nic.in

Table 4 highlighted the households which had completed their 100 days wage employment under the MGNREGA in the study area from 2013 to 2017. In majority of cases it is depicted from the table that very less workers had completed their 100 days wage employment in all the years. For instance, in Pochhal A 1 only 29, 52, 74, 75 out of total respondents had completed 100 days of employment and in Pochhal A 2 only 25, 16, 76 and 130 out of total respondents had completed their 100 days wage rate in respective years. But on the other hand, except certain cases both of the panchayats of Drabshalla block have good position as per as completion of 100 days employment is concerned.

Table No. 5:- List of Completed/Ongoing Assets

\begin{tabular}{|c|c|c|c|c|c|c|c|}
\hline Block & \multirow{3}{*}{$\begin{array}{l}\text { Panchayats } \\
\text { /villages }\end{array}$} & \multicolumn{6}{|c|}{ Works/Assets -2012-16 } \\
\hline \multirow[t]{4}{*}{ Kishtwar } & & \multicolumn{3}{|c|}{ Completed } & \multicolumn{3}{|c|}{ Ongoing } \\
\hline & & $\begin{array}{c}\text { Land } \\
\text { Development }\end{array}$ & $\begin{array}{c}\text { Rural } \\
\text { Connectivity }\end{array}$ & $\begin{array}{c}\text { Flood } \\
\text { Control }\end{array}$ & $\begin{array}{c}\text { Land } \\
\text { Dev }\end{array}$ & $\begin{array}{l}\text { Rural } \\
\text { Cont. }\end{array}$ & Flood Cont. \\
\hline & Pochhal A 1 & 12 & 17 & 13 & 13 & 29 & 15 \\
\hline & Pochhal A 2 & 9 & 33 & 14 & 29 & 101 & 61 \\
\hline \multicolumn{2}{|c|}{ Total } & 21 & 50 & 27 & 42 & 130 & 76 \\
\hline \multirow[t]{2}{*}{ Drabshalla } & Pora Chandalli & 5 & 23 & 9 & 53 & 49 & 16 \\
\hline & Ghan & 35 & 30 & 6 & 58 & 75 & 13 \\
\hline \multicolumn{2}{|c|}{ Total } & 40 & 53 & 15 & 111 & 124 & 29 \\
\hline
\end{tabular}

Source: mgnrega.nic.in

Table 5 revealed status of different works/assets completed and ongoing in the study area i.e. block Kishtwar and block Drabshalla of district Kishtwar from 2012-13-14 to 2015-16. The above figures in table 5 depicted the list of works/assets undertaken/completed or ongoing under MGNREGA. It further explained the priority/preference of the work in panchayats or villages. For instance, rural connectivity was highly preferred in all the panchayats viz. Pochhal A 1 and Pochhal A 2, Ghan, Pora-Chandalli which was followed by flood control and Land development.

Table No. 6:-Timely Disbursement of Wages and Complete Payments

\begin{tabular}{ccccc}
\hline Block & Villages & Yes (In \%) & No (In \%) & Do not know (In \%) \\
\hline Kishtwar & Pochhal A 1 & 0 & 100 & 0 \\
& Pochhal A 2 & 0 & 100 & 0 \\
Drabshalla & Ghan & 0 & 100 & 0 \\
& Pora Chandalli & 0 & 100 & 0 \\
\hline
\end{tabular}

Source: field Survey, 2016 
Data from the field reflected that wage payment in the study area must be the main concern. The respondents stated that besides delayed payments, wages were not paid on the basis of guidelines. Maximum of the beneficiaries highlighted that they receive their wages usually after more than 15 days or even after 6-7 months \& even after year in some cases. After interactions with the MGNREGA workers it came to limelight that some of the respondents were not even able to get the complete payments due to lack of awareness about the minimum wage rate and other certain factors. Majority of the beneficiaries expressed the system of wage payments should be as per the guidelines so as to make programme truly a beneficial one. The delay in payments had affected the daily life of the respondents (see Table No 6).

Table No.7:- Employment Provided Period Wise

\begin{tabular}{|c|c|c|c|c|c|c|}
\hline \multirow{2}{*}{$\begin{array}{c}\text { Panchayats/Blo } \\
\text { cks }\end{array}$} & \multicolumn{2}{|c|}{ No of HHs Provided Employment } & \multicolumn{3}{c|}{ No of Person's Days Generated } \\
\cline { 2 - 7 } & $\mathbf{2 0 1 3 - 1 4}$ & $\mathbf{1 4 - 1 5}$ & $\mathbf{1 5 - 1 6}$ & $\mathbf{2 0 1 3 - 1 4}$ & $\mathbf{1 4 - 1 5}$ & $\mathbf{1 5 - 1 6}$ \\
\hline Pochhal A 1 & 222 & 275 & 338 & 15958 & 17070 & 24156 \\
\hline Pochhal A 2 & 302 & 318 & 301 & 23079 & 16362 & 22193 \\
\hline Ghan & 238 & 246 & 237 & 22968 & 13712 & 18199 \\
\hline Pora-Chandali & 294 & 460 & 310 & 29640 & 22300 & 26140 \\
\hline
\end{tabular}

Source: mgnrega.nic.in

During financial years 2013-14-15to 16, 835 households in Pochhal A 1, 921 households in Pochhal A 2, 721 households in Ghan and 1064 households in Pora- Chandalli Panchayats have been provided employment in Kishtwar district i.e. block Kishtwar and block Drabshalla generating 57184 thousand person days as shown in Table No 7 in Pochhal A 1, 61634 in Pochhal A2, 54879 in Ghan and 25177 in Pora-Chandalli. Also the table shows that the No. of households who have been provided job cards and employment has been increased, decreased and increased as well as decreased in some cases i.e. in Pochhal A from 222 in year 2013-14 to 275 in year 2014-15 to 338 in year 2015-2016, in Pochhal A 2 from 302 to 318 to 301, In Ghan, from 238 to 246 to 237 and in PoraChandalli, from 294 to 260 to 210. Similarly the both increase as well as decrease was noticed so for as generation of persons days are concerned. In other words it can be mention that there was no consistency in providing the employment or in generating the person days.

\section{Key findings of the study:-}

Therefore, it is discernible from the above discussion that trends in each Panchayats of two blocks are unique and are sometimes very similar depending upon the parameters. The trends emerging from all the four panchayats were highlighted in the form of following main findings as it summarizes some of the important variables covered under the study.

1. Lack of awareness among majority of respondents about minimum wage rate in all three panchayats was noticed;

2. There was delay in disbursing the payment and incompetency in providing complete wages;

3. High priority/ preference to rural connectivity in all panchayats was noticed;

4. There were very less works completed as compare to works ongoing and

5. Very less respondents could be seen who have completed their 100 days during all covered financial years in majority cases.

\section{Conclusion and Recommendations:-}

MGNREGA programme has been implemented with the purpose of providing relief to the rural poor as it is an additional source of employment $\&$ income in the study area. The act has played a vital role in providing the employment generating the person's days in thousands to secure the livelihood in selected rural area. It has also emphasized on creating certain assets to develop the rural infrastructure. Thus it becomes significant that more awareness should be provided to local people about various entitlements of the MGNREGA act so that they may participate fully in this scheme. On the basis of above discussions it can be concluded that the implementation of the scheme in the study area has covered all the sections of society and community (as the case may be) so for as providing of job cards or employment generation is concerned. But there is a low awareness among the workers on NREGA in general and minimum wage rate in particular in the area that has affected the accessibility, completion of 100 days by an employee. The further obstacles in the way of achieving such a goal are delayed payments, incomplete wages and disobedience towards 2005 guidelines- continuously updated by the government from time to 
time. Hence, there is a growing concern among the workers to know and become more aware of NREGS. The workers need to get empowered through NREGS as prescribed in the Act. The awareness among the workers can play a significant role in addressing all the issues viz. delay in payments, incomplete wages, non allocation of extra compensation and unemployment allowance and above all in implementing the scheme in all aspects.

\section{References:-}

1. Mishra, Kumar Sushanta. Asset Creation under MGNREGA: A Study in Three Districts of Madhya Pradesh. Indore: IMJ (2011) 19-20.

2. Haque, T. Socio Economic Impact of Implementation of Mahatma Gandhi National Rural Employment Guarantee Act in India. New Delhi: SAGE, 2011.

3. CN, Kantharaju. "Impact of MGNREGA on Employment Generation and Assets Creations in Tumkur District of Karnataka State" Thesis, University of Agriculture Sciences, Bengaluru, 2011, Print.

4. Singh, Nandini. Impact of MGNREGA on Migration and Asset Creation. Report. Andhrapradesh: International Crop Research Institute, 2013.

5. Bhaumik, Arindam Banik and Pradip. Are Poverty Redection Programmes Less Effective in Troubled States? An Empirical Household Level Investigation in Rural India Italy: University of Bergamo, 2008.

6. No.J-12020/1/2013-MGNREGA -IV Government of India Ministry of Rural Development Department of Rural Development retrieved March 11, 2016, from NREGA website, http://nrega.nic.in

7. Economic Survey 2014-15 Volume 1 retrieved March 11, 2016 from http://www.ecostatjk.nic.in.

8. MGNREGA Act, 2005 (Operational Guidelines 2013, 4 ${ }^{\text {th }}$ Edition) retrieved July, 2017 from http://nrega.nic.in/Circular_Archive/archive/Operational_guidelines_4thEdition_eng_2013.pdf. 